УДК 334.024: 334.021.1

Вавдіюк Н.С., д.е.н., професор

Завідувачка кафедри менеджменту

Vavdiiuk N., Doctor of Economics Science, Professor

Head of Management Department

https://orcid.org/0000-0001-9100-3722

\title{
УДОСКОНАЛЕННЯ ВИБОРУ СТИЛІВ ЛІДЕРСТВА В СИТУАЦІЙНОМУ МЕНЕДЖМЕНТІ
}

\author{
Луцький національний технічний університет
}

\begin{abstract}
У статті розглянуто ситуаційні змінні вибору стилів лідерства за методом Ф.Е.Фідлера. За результатами опитування 28 керівників структурних підрозділів комерційної організації були визначені показники найменш сприятливого співробітника, встановлено взаємозв'язки «керівник-підлеглий», визначено структурованість чи неструктурованість завдання, достатність посадових повноважень. 3 часу проведення наукового спостереження керівники були згруповані в першу групу з хорошими стосунками «керівник-підлеглий», структурованими завданнями та достатніми посадовими повноваженнями - 6 осіб, що становить 21,4\% від загальної кількості респондентів. Друга група при хороших відносинах «керівник-підлеглий», структурованих завданнях i недостатньо службових повноважень містить 2 особи (7,1\%). Третя група 3 хорошими відносинами керівникпідлеглий», неструктурованими завданнями, але достатніми посадовими повноваженнями включає 5 осіб, або 17,9\% від загальної кількості респондентів. Четверта група 3 добрими відносинами «керівник-підлеглий», структуровані завдання, але недостатніми посадовими повноваженнями включала 8 осіб, що становить 28,6\% від загальної кількості респондентів. Оскільки керівники вважали, що вони мають сильний достатній авторитет, i поділ цих груп проводився на тих, хто має погані стосунки «керівник-підлеглий», включав модельні тести в групах ситуацій управління: п'ята - а це 4 особи (14,3\%)); шоста - 2 особи (7,1\%), сьома: 1 особа $(3,6 \%)$. Менеджери, які отримали низькі оцінки НСП (1-3 бали) мотивовані завданням, суворо оцінюють своїх підлеглих і часто використовують суворий контроль: завдання виконуються, цілі досягаються, керівник, мотивований завданнями, задовольняється деталями та спостереженням за досягненням їх результатів. Менеджери, які отримали високі оцінки НСП (7-8 балів) є особами, мотивованими стосунками в колективі, зосереджені на соціальній взаємодії. Менеджери, які мають середні бали (4-6 балів), залежно від того, наскільки їх показник наближений до верхнього чи нижнього значення шкали, можуть бути як орієнтованими на завдання, так і на стосунки. За результатами опитування 28 керівників структурних підрозділів організації визначено показники дослідження, встановлено взаємовідносини «керівник-підлеглий», визначено структурованість завдань, достатність службових повноважень.

Встановлено гіпотези дослідження: зі зростанням орієнтації керівника на завдання зростатиме групова взаємодія підлеглих, зростатиме і результативність діяльності і навпаки. Якщо гіпотеза Н0 - кореляційний зв'язок між якісними ознаками не значимий, то гіпотеза відхиляється; конкуруюча гіпотеза Н1 - кореляційний зв'язок між якісними ознакам значимий, то гіпотеза приймається. Для підтвердження гіпотез розраховано коефіцієнти рангової кореляції Спірмена ( $\mathrm{rR}=0,99$; Tkp $<\mathrm{p}, 0,17<2,571)$; Кендалла $(=0,9 ; \tau>\mathrm{Tkp}$, а саме $0,9>0,62)$ та прийнято гіпотезу Н1 про те, що ранговий кореляційний зв'язок за оцінками двох тестів є значущим. Встановлено значний кореляційний зв'язок між аналізованими ознаками. Керівник, орієнтований на стосунки, $\epsilon$ ефективним, коли ситуаційні фактори поєднуються і є сприятливими для керівника, який має помірний контроль над ситуацією. Якщо ситуаційні чинники створюють ситуацію, що є дуже сприятливою або дуже несприятливою для керівника, очікується, що керівники, орієнтовані на завдання, будуть ефективнішими. Керівник, який прийняв певний стиль управління, повинен відповідати управлінській ситуації, в якій цей стиль був би більш ефективним. Залежно від ситуаційних змінних управлінської ситуації сформовано рекомендації застосування стилів управління.
\end{abstract}

Ключові слова: ситуаційний менеджмент, ситуаційні чинники, ефективність управління, лідерство, стилі лідерства.

\section{IMPROVING THE CHOICE OF LEADERSHIP STYLES IN THE SITUATIONAL MANAGEMENT}

\author{
Lutsk National Technical University
}

The article considers the situational variables of the choice of control stitches by the method of F. E. Fiedler. Having processed electronic questionnaires of 28 heads of structural subdivisions of a commercial organization, the level 
of LPC was assessed, as well as 28 management situations concerning group interaction, structured and unstructured tasks, observance of official powers by the head were analyzed. Since the organization of the scientific observation, some managers have been grouped into the first group with good relations "supervisor-subordinate", structured tasks and sufficient official authority of 6 people, which is $21.4 \%$ of the total number of respondents.The second group with good relations "manager-subordinate", structured tasks and insufficient official powers includes 2 people (7.1\%). The third group with good relations "manager-subordinate", unstructured tasks, but sufficient official powers includes 5 people, $17.9 \%$ of the total number of respondents.The fourth group with good relations "supervisor-subordinate", structured tasks, but insufficient official powers included 8 people, which is $28.6 \%$ of the total number of respondents. Because managers believed that they had strong sufficient authority, and the division of these groups was carried out on those who have a bad relationship "manager-subordinate" included model tests in groups of management situations: the fifth - and this is 4 people (14.3\%) ); sixth - 2 people (7.1\%), seventh: 1 person (3.6\%). Managers who received low LPC scores (1-3 points) are motivated by the task, strictly evaluate their subordinates and often use strict control. However, if the tasks are performed, the goals are achieved, the leader, motivated by the task, is satisfied with the details and observation of everyday events. Managers who received high LPC scores (7-8 points) are motivated relationships, focusing on social interaction. Managers who have average scores (4-6 points), depending on how close their score is to the high or lower end of the scale, can be both task-oriented and relationship-oriented leaders. According to the results of the survey of 28 managers of structural subdivisions of organization, the indicators of the least favorable employee were determined, the "manager-subordinate" relationship was established, the structure or unstructured task, the sufficiency of official powers were determined.

The hypotheses of the research are established: with the growth of the leader's orientation to the task the group interaction of subordinates will grow, the efficiency of activity will increase and vice versa. If hypothesis $\mathrm{H} 0$ - the correlation between qualitative features is not significant, the hypothesis is rejected; competing hypothesis H1 - the correlation between qualitative features is significant, the hypothesis is accepted. To confirm the hypotheses, Spearman's rank correlation coefficients were calculated $(\mathrm{rR}=0.99$; $\mathrm{Tkp}<\mathrm{p}, 0.17<2.571)$; Kendall $(0.9 ; \tau>\mathrm{Tkp}, 0.9>0.62)$ and hypothesis $\mathrm{H} 1$ was accepted that the rank correlation relationship according to the estimates of the two tests is significant. There is a significant correlation between the analyzed features. A relationship-oriented leader is effective when situational factors are combined and are conducive to a leader who has moderate control over the situation. If situational factors create a situation that is very favorable or very unfavorable for the manager, task-oriented managers are expected to be more effective. A manager who has adopted a certain management style must respond to a management situation in which this style would be more effective. Depending on the situational variables of the management situation, recommendations for the use of management styles are formed.

Key words: situational management, situational factors, management efficiency, leadership, leadership styles.

Постановка проблеми у загальному вигляді та іï зв'язок 3 важливими науковими та практичними завданнями. Ефективний менеджмент організації залежить від реалізації основних функцій: організації, планування, мотивації, контролю, ситуаційних чинників, які впливають на реалізацію стилю управління. Чи здатний керівник організувати підлеглих на досягнення результатів діяльності і одночасно, аби підлеглі були задоволені своєю роботою? Це постійно існуюча дилема, від якої залежить кінцевий результат ефективності управління організацією та ії структурними підрозділами. Завдання керівника структурного підрозділу полягатиме в тому, щоб забезпечити сприятливий соціально-психологічний клімат в колективі та обрати такий стиль управління, який сприятиме підвищенню показників результативності.

Аналіз останніх досліджень i публікацій, в яких започатковано вирішення проблеми. Проблеми вибору стилю управління керівниками розглянута в наукових працях: Дж. Гарсіа, Дж. Голд, А. Мамфорд, Р. Торпе, Ф. Е. Фідлера, Дж. Шермерхорна та ін. В теорії ситуаційного менеджменту Ф. Е. Фідлера зазначено, що ефективність лідерства - це функція, що відповідає стилю управління керівника та управлінській ситуації. Якщо стиль управління відповідає управлінській ситуації, керівник буде ефективним, а в протилежному випадку - не буде ефективним.

Незважаючи на те, що нові підходи до питання лідерства були впроваджені та вивчені за різними видами стилів управління, залишаються нез'ясованими питання визначення стилю управління підлеглими залежно від орієнтації керівників на завдання чи на відносини в організації.

Мета статті полягає у формуванні підходів до вибору стилю управління в організації залежно від управлінської ситуації. 
Виклад основного матеріалу дослідження 3 повним обгрунтуванням отриманих наукових результатів. Дослідження Фред Едварт Фідлер розпочав у 1958 році 3 обгрунтування ймовірнісної теорії менеджменту [1, с. 149-190; 2, с. 137-149], ефективність якої визначається взаємодією особистісних якостей керівника і аспектів ситуації, які й в континуумі вимагають реалізацію різних стилів керівництва. Відповідно, існує набір факторів, що впливають на ситуацію та визначають тип стилю управління. Згідно постулатів теорії, серед керівників є особистості, орієнтовані на людей, і особистості, орієнтовані на завдання. Керівник якого саме типу виявиться ефективним в кожній конкретній ситуації, залежить від того, яким чином здійснюватиметься ситуаційний контроль. Ефективність контролю управління в певній ситуації залежить від трьох чинників: від відносин керівника 3 підлеглими, від ступеня структурованості завдання, від посадових повноважень. Якщо керівник управляє процесом виконання структурованої та монотонної роботи, володіє авторитетом у підлеглих та відповідними посадовими повноваженнями щодо дотримання трудової дисципліни, то умови управління $\epsilon$ сприятливими, а керівник - контролює управлінську ситуацію [1, с. 149-190; 2, с. 137-149]. Керівник, орієнтований на завдання, буде ефективний як в сприятливих, так і в настільки ж несприятливих умовах, в той час як керівник, орієнтований на підлеглих - буде ефективний в сприятливій управлінській ситуації.

У 1980 роках піддавались критиці виведені постулати щодо достовірності запропонованих методів управління в певних ситуаціях. Це пояснюється тим, що більша частина таких досліджень виконана не в польових (на конкретних прикладах), а в лабораторних умовах. А тому, потребували доведення достовірності ймовірнісної теорії менеджменту Ф. Е. Фідлера в частині дослідження в реальних виробничих умовах тих результатів, які були отримані вченим в лабораторії. 3 цією метою теорія когнітивного ресурсу Ф. Е. Фідлера розвинулась у 1984-1987 роках за контрактом MDA903-М-3668 3 науково-дослідним інститутом наук про поведінку [3, с. 54]. Як зазначає Дж. Шермерхорн: «В теорії когнітивного ресурсу Ф. Е. Фідлера ефективність діяльності команди залежить від відповідного поєднання стилю керівництва та управлінською ситуацією» [4, с. 297].

Основні положення теорії когнітивних ресурсів потягали в тому, що групи отримують різні когнітивні ресурси від керівника, які залежать від певної ситуації. А когнітивні ресурси залежать від когнітивних здібностей керівників: інтелект, професійна компетентність, навички. Рівень когнітивних здібностей керівника залежить від встановлених планів, стратегій, прийнятих рішень, які будуть виконувати підлеглі. Чим більш здібний керівник, тим ефективнішими будуть плани, рішення і стратегія. Якщо група підлеглих підтримує виконання цілей, визначених керівником, і якщо останній не відчуває стресу від управління ситуацією, то його плани та програми будуть реалізовані за інших рівних умов.

Відповідно до положень теорії когнітивного ресурсу Ф. Е. Фідлера визначимо три ситуаційні чинники, що впливають на ефективність управління, а саме: відносини керівникпідлеглий, структура завдань та владні повноваження. Опишемо основні ситуаційні чинники, які впливатимуть на вибір стилю управління в табл. 1.

Таблиия 1

Ситуаційні чинники вибору стилю управління

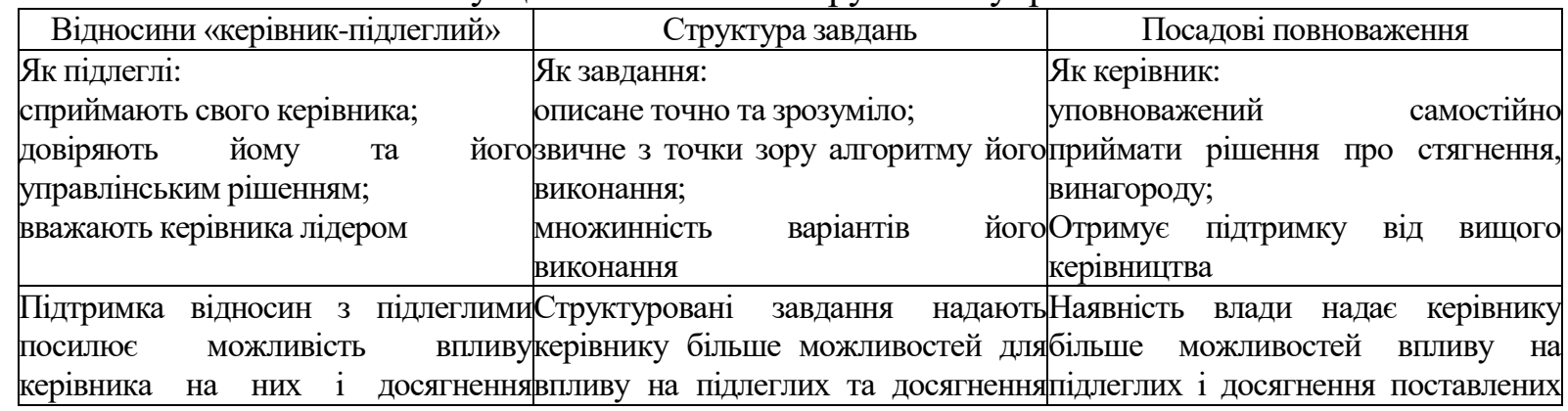




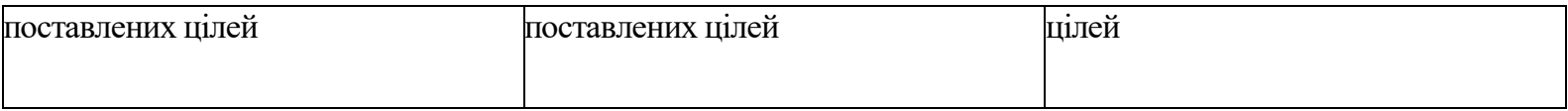

Примітка. Складено за [1, с. 149-190; 2, с. 137-149, 3$]$

Відносини керівник-підлеглий пов'язані з організацією взаємодії між підлеглими, ступенем їх ефективності. Відповідно, у ситуаціях, коли керівника приймають підлеглі, він опиниться у більш сприятливій ситуації очолити колектив і діяти ефективно. Навпаки, у ситуаціях, коли рівень лояльності до керівника низький, ефективність управління виявиться низькою. Якщо підлеглі довіряють керівнику, поважають його, впевнені в ньому, взаємовідносини оцінюються як сприятливі.

Структура завдання. Завдання можуть бути традиційні (монотонні) і структуровані; творчі (креативні) і неструктуровані. Чітко структуроване завдання зрозуміле керівнику та підлеглим, а неструктуроване завдання означає більш складну управлінську ситуацію. Погоджуємось з Дж. Голд, Р. Торпе, А. Мамфорд, які вважають, що фактори, що визначають характер структури завдання, включають ступінь легкості розуміння завдання відповідними сторонами, способи виконання завдання та кількість правильних рішень проблеми [5].

Отже, ситуаційний вимір структурованості завдання дозволяє виявити ті завдання, які для керівника та його підлеглих є постійними і традиційними до виконання, та ті, які є новими та складними і вимагають застосування когнітивних ресурсів.

Посадові повноваження - це рівень формальної влади керівника над підлеглими. Більш сприятлива ситуація, коли менеджер має достатньо повноважень, і не дуже сприятлива, коли повноваження обмежені, і менеджер не завжди може мотивувати підлеглих.

Отже, достатність посадових повноважень керівника можна оцінити через застосовану ним систему винагород та покарань. Відповідно, високий рівень посадових повноважень створив би сприятливу ситуацію для лідера. Оцінка ситуаційних чинників вибору стилю управління може бути застосована для аналізу рівня ефективності його діяльності. На рис.1 подамо змістові елементи теорії когнітивного ресурсу Ф. Е. Фідлера.

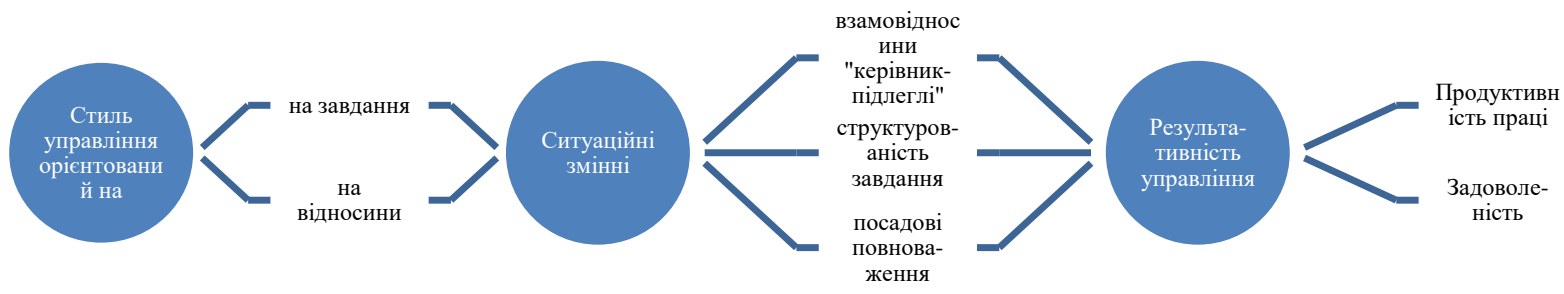

Рис. 1. Змістові елементи теорії когнітивного ресурсу Ф. Е. Фідлера

Примітка. Складено автором за [1, с. 149-190; 2, с. 137-149, 3]

Якщо відносини керівник-підлеглий хороші, завдання добре структуровані, чіткі посадові повноваження - доцільно орієнтуватись на реалізацію завдання. Чіткі посадові повноваження посилюють можливість впливу на підлеглих.

Якщо ж відносини керівник-підлеглий погані, структура завдання нечітка, то, незалежно від того, сильна або слабка посадова влада, орієнтація керівника є кращою на завдання.

Якщо відносини керівник-підлеглий хороші при нечіткій структурованості завдання, або відносини керівник-підлеглий погані при чіткій структурованості завдання, то доцільно орієнтуватися більше на взаємини з підлеглими. Чіткі посадові обов'язки в такі ситуації $\epsilon$ додатковою перевагою, однак суттєво на управління ситуацією не вплинуть. 
3 метою підвищення ефективності управління необхідно звернути увагу на наведені чинники ситуаційних вимірів, а саме: покращення відносин між керівником та підлеглими; оптимізації структури завдань; визначення посадових повноважень керівника.

Оцінимо співвідношення між стилем керівництва та ефективністю управління. Ефективність управління керівників структурного підрозділу організації проводилась шляхом опитування безпосередніх керівників відділень протягом 2 місяців за відповідними робочими обов'язками та особистими характеристиками, які $\epsilon$ важливими для виконання роботи та досягнення запланованих показників Основними вимогами для опитування керівників структурних підрозділів були: визначення показника НПС (найменш сприятливого співробітника), встановлення зв'язків «керівник-підлеглий», структуровані чи неструктуровані завдання, посадові повноваження.

Відносини «керівник-підлеглий» були класифіковані як хороші або погані в результаті сприйняття керівниками групової атмосфери, на що вказували їх відповіді на 10 семантичних диференціальних твердження, що описують групову атмосферу [6]. Ці відповіді були узагальнені та розділені на дані високих та низьких груп (хороші та погані), відбираючи верхню та нижню третину балів. Завдання були класифіковані як структуровані або неструктуровані, а посадові повноваження визначались як достатні чи недостатні серед керівників, що заповнювали анкети Ханта [7].

Опрацювавши електронні анкети 28 керівників структурних підрозділів комерційної організації, оцінено рівень НПС, а також проаналізовано 28 управлінських ситуацій щодо групової взаємодії, структурованих та неструктурованих завдань, дотримання керівником посадових повноважень.

3 моменту організації наукового спостереження, окремих керівників вдалось згрупувати в першу групу з хорошими відносинами «керівник-підлеглий», структурованими завданнями та достатніми посадовими повноваженнями 6 осіб, а це 21,4\% від загальної кількості опитаних.

До другої групи з хорошими відносинами «керівник-підлеглий», структурованими завданнями та недостатніми посадовими повноваженнями віднесено 2 особи (7,1\%).

До третьої групи з хорошими відносинами «керівник-підлеглий», неструктурованими завданнями, але достатніми посадовими повноваженнями віднесено 5 осіб, 17,9\% від загальної кількості опитуваних.

До четвертої групи з хорошими відносинами «керівник-підлеглий», структурованими завданнями, але недостатніми посадовими повноваженнями віднесено 8 осіб, а це 28,6\% від загального числа опитаних.

Оскільки керівники вважали, що вони мають сильні достатні владні повноваження, а поділ цих груп здійснювали на тих, хто має погані відносини «керівник-підлеглий» включені тести моделі в групах управлінських ситуацій: п'ятій - а це 4 особи $(14,3 \%)$; шостій - 2 особи (7,1\%), сьомій: 1 особа $(3,6 \%)$.

Керівники, які отримали низькі показники НСП (1-3 бали) мотивовані завданням, суворо оцінюють своїх підлеглих і часто використовують жорсткий контроль. Однак, якщо завдання виконуються, цілі досягаються, то керівник, вмотивований завданням, задоволений деталями та спостереженням за повсякденними подіями.

Керівники, які отримали високі бали НПС (7-8 балів) є мотивованими стосунками, зосереджуються на соціальній взаємодії.

Керівники, які мають середні бали (4-6 балів) залежно від того, наскільки близький їхній бал до високого або нижнього кінця шкали, вони можуть належати до керівників, що орієнтовані на завдання, так і до керівників, орієнтованими на відносини.

Сформуємо гіпотези дослідження: зі зростанням орієнтації керівника на завдання зростатиме групова взаємодія підлеглих, зростатиме і результативність діяльності і навпаки: гіпотеза $\mathrm{H}_{0}-$ кореляційний зв'язок між якісними ознаками незначимий, то гіпотеза 
відхиляється; конкуруюча гіпотеза $\mathrm{H}_{1}$ - кореляційний зв'язок між якісними ознакам значимий, то гіпотеза приймається.

Для перевірки точності сформованих гіпотез доцільно здійснювати розрахунок i коефіцієнта рангової кореляції Кендалла. 3 метою виявлення зв'язку між результативною ознакою - обсяг чистого прибутку i фактором - кількість керівників за типами управлінських ситуацій орієнтації на завдання чи на відносини здійснимо перевірку достовірності гіпотез за розрахунком коефіцієнтів рангової кореляції Спірмена та Кендалла.

Для підтвердження гіпотези розрахуємо коефіцієнт рангової кореляції Спірмена для досліджуваних груп керівників відділень за типами управлінських ситуацій та показниками чистого прибутку в середньому за досліджуваний період. Відповідно, фактором X виступатимуть кількість керівників, які обрали діяльність в певній управлінській ситуації, а результативною ознакою Y - обсяг чистого прибутку в тис. грн. В табл. 2 присвоїмо ранги ознаці Y і фактору X.

Таблиия 2

Встановлення рангів ознаці Y (обсяг чистого прибутку) і фактору X (кількість керівників за типами управлінських ситуації)

\begin{tabular}{|c|c|c|c|}
\hline $\begin{array}{c}\text { Кількість керівників за типами управлінських } \\
\text { ситуциї, осіб-X }\end{array}$ & $\begin{array}{c}\text { Обсяг чистого прибутку, } \\
\text { тис грн-Y }\end{array}$ & Ранг X, $\mathrm{d}_{\mathrm{x}}$ & Ранг $\mathrm{Y}, \mathrm{d}_{\mathrm{y}}$ \\
\hline 6 & 1900 & 6 & 6 \\
\hline 2 & 650 & 2 & 3 \\
\hline 5 & 1380 & 5 & 5 \\
\hline 8 & 2100 & 7 & 7 \\
\hline 4 & 820 & 4 & 4 \\
\hline 2 & 400 & 2 & 2 \\
\hline 1 & 250 & 1 & 1 \\
\hline
\end{tabular}

Примітка. Розраховано автором

Так як в матриці таблиці 2 є пов’язані ранги (однаковий ранговий номер) 1-го ряду, доцільно здійснити їх переформування. Переформування рангів проводимо без зміни важливості рангу, тобто між ранговими номерами повинні зберегтися відповідні співвідношення (більше, менше або дорівнює). Також не рекомендується ставити ранг вище 1 і нижче значення рівного кількості параметрів (в досліджуваному випадку n=7).

Переформування рангів проведемо в табл. 3.

Таблиия 3.

Переформування рангів ознаці Y (обсяг чистого прибутку) і фактору X (кількість керівників, які обрали стиль управління)

\begin{tabular}{|c|c|c|}
\hline Номери місць в упорядкованому ряду & Розташування факторів за оцінкою експерта & Нові ранги \\
\hline 1 & 1 & 1 \\
\hline 2 & 2 & 2,5 \\
\hline 3 & 2 & 2,5 \\
\hline 4 & 4 & 4 \\
\hline 5 & 5 & 5 \\
\hline 6 & 6 & 6 \\
\hline 7 & 7 & 7 \\
\hline
\end{tabular}

Примітка. Розраховано автором

Розрахуємо матрицю рангів в таблиці 4.

Таблиия 4.

Матриця рангів Y (обсяг чистого прибутку) і фактору Х(кількість керівників, які обрали

стиль управління)

\begin{tabular}{|c|c|c|}
\hline Ранг $\mathrm{X}, \mathrm{d}_{\mathrm{x}}$ & Ранг $\mathrm{Y}, \mathrm{d}_{\mathrm{y}}$ & $\left(\mathrm{d}_{\mathrm{x}}-\mathrm{d}_{\mathrm{y}}\right)^{2}$ \\
\hline 6 & 6 & 0 \\
\hline 2,5 & 3 & 0,25 \\
\hline
\end{tabular}




\begin{tabular}{|c|c|c|}
\hline 5 & 5 & 0 \\
\hline 7 & 7 & 0 \\
\hline 4 & 4 & 0 \\
\hline 2,5 & 2 & 0,25 \\
\hline 1 & 1 & 0 \\
\hline 28 & 28 & 0,5 \\
\hline
\end{tabular}

Примітка. Розраховано автором

Перевіримо правильність складання матриці через розрахунок контрольної суми за формулою:

$$
\sum x_{i j}=\frac{(1+n) n}{2}=\frac{(1+7) 7}{2}=28 .
$$

Сума по стовпчиках матриці рівні між собою і контрольної суми, значить, матриця складена правильно.

Оскільки серед значень ознак Y (обсяг чистого прибутку) і фактору X (кількість керівників, які обрали стиль управління) зустрічається кілька однакових, тобто утворюються пов’язані ранги, то в такому випадку коефіцієнт Спірмена розрахуємо за формулою:

$$
p=1-\frac{\sum 6 d^{2}+A+B}{n^{3}-n}
$$

де $A=\frac{1}{12} \sum\left(A_{j}^{3}-A_{j}\right), B=\frac{1}{12} \sum\left(B_{k}^{3}-B_{K}\right)$, управління);

j - номери зв’язок по порядку для ознаки х (кількість керівників, які обрали стиль

$\mathrm{A}_{j}$ - число однакових рангів в ј-й зв'язці з х (кількість керівників, які обрали стиль управління);

$\mathrm{k}$ - номери зв'язок по порядку для ознаки у (обсяг чистого прибутку);

$\mathrm{B}_{\mathrm{k}}$ - число однакових рангів в k-й зв'язці з у (обсяг чистого прибутку).

Розрахуємо А та B: $\mathrm{A}=\left[\left(2^{3}-2\right)\right] / 12=0,5 ; \mathrm{D}=\mathrm{A}+\mathrm{B}=0,5$. Далі розрахуємо коефіцієнта кореляції Спірмена за формулою:

$$
r_{R}=1-\frac{6\left[\sum_{i} d_{i}^{2}+\sum_{j} \frac{t_{j}^{3}-t_{j}}{12}\right]}{n\left(n^{2}-1\right)},
$$

де $\mathrm{r}_{\mathrm{R}}$ - коефіцієнт кореляції рангів і лежить між -1 і 1 включно з цих двох значень;

$\mathrm{d}_{\mathrm{i}}=\mathrm{x}_{\mathrm{j}}-\mathrm{y}_{\mathrm{j}}-$ різниця рангів для i-го індивіда i n позначає кількість особин.

За формулою 2 розрахуємо коефіцієнт рангової кореляції Спірмена:

$$
r_{R}=1-\frac{6 \cdot 0,5+0,5}{7^{3}-7}=0,99
$$

Отже, зв'язок між результативною ознакою Y (обсяг чистого прибутку) і фактором X (кількість керівників за типами управлінських ситуацій) є сильним і прямим.

Розрахуємо значимість коефіцієнта рангової кореляції Спірмена. Для того щоб при рівні значущості $\alpha$ перевірити нульову гіпотезу $\mathrm{H}_{0}$ про рівність нулю генерального коефіцієнта рангової кореляції Спірмена при конкуруючій гіпотезі $\mathrm{H}_{1}, \mathrm{p} \neq 0$, слід розрахувати критичну точку за формулою:

$$
T_{k p}=t(a, k) \cdot \sqrt{\frac{1-p^{2}}{n-2}}
$$

де $\mathrm{n}$ - обсяг вибірки;

p - вибірковий коефіцієнт рангової кореляції Спірмена; 
$\mathrm{t}(\alpha, \kappa)$ - критична точка двосторонньої критичної області, яку знаходять за таблицею критичних точок розподілу Стьюдента, за рівнем значущості $\alpha$ і числа ступенів свободи $\mathrm{k}=\mathrm{n}$ 2.

Якщо $|\mathrm{p}|<\mathrm{T}_{\mathrm{kp}}-$ немає підстав відкинути нульову гіпотезу $\left(\mathrm{H}_{0}\right)$. Ранговий кореляційний зв'язок між якісними ознаками не значимий.

Якщо $|\mathrm{p}|>\mathrm{T}_{\mathrm{kp}}$ - нульову гіпотезу $\left(\mathrm{H}_{0}\right)$ відкидають. Між якісними ознаками існує значний ранговий кореляційний зв'язок.

За таблицями Стьюдента знаходимо $\mathrm{t}(\alpha / 2, \mathrm{k})=(0,05 / 2 ; 5)=2,571$.

$$
T_{k p}=2,571 \cdot \sqrt{\frac{1-0,99^{2}}{7-2}}=0,17 .
$$

Оскільки $0,17<2,571$, то відхиляємо гіпотезу про рівність 0 коефіцієнта рангової кореляції Спірмена. Це дозволяє стверджувати, що розрахований коефіцієнт рангової кореляції є статистично значущим і взаємозв'язок між оцінками ознак $є$ значимий.

Для підтвердження гіпотези розрахуємо коефіцієнт рангової кореляції Кендалла для досліджуваних груп керівників відділень за типами управлінських ситуацій та показниками чистого прибутку в середньому за досліджуваний період. Присвоїмо ранги ознаці Y (обсяг чистого прибутку в тис. грн.) і фактору X (кількість керівників, які обрали діяльність в певній управлінській ситуації). Розташуємо аналізовані показники так, щоб їх ранги по X представити значеннями натурального ряду. Так як оцінки, приписувані кожній парі цього ряду, позитивні, значення «+1», що входять до Р, будуть породжуватися лише тими парами, ранги яких по Ү утворюють прямий порядок. Їх легко підрахувати, зіставляючи послідовно ранги кожного об'єкта в ряду Ү з іншими значеннями.

Розрахунок коефіцієнт Кендалла здійснимо за формулою:

$$
\tau=\frac{P-Q}{\frac{1}{2} N(N-1)}
$$

Де Р - кількість узгоджених пар;

Q - кількість неузгоджених пар;

$\mathrm{N}$ - обсяг вибірки.

Спрощуємо обчислення форм. 4: $\tau=1-\frac{4 Q}{N(N-1)}$, або $\tau=\frac{4 P}{N(N-1)}-1$.

В знаменнику подається загальна кількість утворених пар досліджуваних явищ. Розраховане значення коефіцієнта Кендалла може знаходитись в діапазоні від -1 до 1. Це можемо пояснити наступними твердженнями:

якщо узгодженість між двома величинами $\mathrm{X}$ (кількість керівників, які обрали діяльність в певній управлінській ситуації) та Y (обсяг чистого прибутку в тис. грн.) є ідеальною (тобто дві величини збігаються), то коефіцієнт матиме значення 1;

якщо розбіжність між двома величинами X (кількість керівників, які обрали діяльність в певній управлінській ситуації) та Y (обсяг чистого прибутку в тис. грн.) є ідеальною (тобто вони мають різні порядки зростання), то коефіцієнт дорівнюватиме -1;

якщо X та Ү незалежні, то коефіцієнт буде прямувати до нуля.

Отже, впорядкуємо дані по X (кількість керівників, які обрали діяльність в певній управлінській ситуації) в таблиці 2.7. Так, в ряді Ү (обсяг чистого прибутку в тис. грн.) праворуч від 1 розташовано 6 рангів, що перевершують 1, отже, 1 переходить в Р доданок 6.

Таблиия 5

Переформування рангів фактору X (кількість керівників, які обрали стиль управління) ознаці Ү (обсяг чистого прибутку)

\begin{tabular}{|c|c|c|c|c|c|}
\hline $\begin{array}{c}\text { Кількість керівників за типами } \\
\text { управлінських ситуації, осіб -X }\end{array}$ & Обсяг чистого прибутку, тис грн -Y & Ранг X, $\mathrm{d}_{\mathrm{x}}$ & Ранг $\mathrm{Y}, \mathrm{d}_{\mathrm{y}}$ & $\mathrm{P}$ & $\mathrm{Q}$ \\
\hline
\end{tabular}




\begin{tabular}{|c|c|c|c|c|c|}
\hline 1 & 250 & 1 & 1 & 6 & 0 \\
\hline 2 & 650 & 2 & 3 & 4 & 1 \\
\hline 2 & 400 & 3 & 2 & 4 & 0 \\
\hline 4 & 820 & 4 & 4 & 3 & 0 \\
\hline 5 & 1380 & 5 & 5 & 2 & 0 \\
\hline 6 & 1900 & 6 & 6 & 1 & 0 \\
\hline 8 & 2100 & 7 & 7 & 0 & 0 \\
\hline
\end{tabular}

Примітка. Розраховано автором

Праворуч від 3 стоять 4 рангу, що перевершують 3 (це 4, 5, 6, 7), тобто в Р увійде 4 і т. д. В результаті: $\mathrm{P}=20$ і $з$ використанням формули 4 маємо:

$$
\tau=\frac{20-1}{\frac{1}{2} 7(7-1)}=0,9 .
$$

За спрощеним формулами отримаємо такі самі значення.

Для того щоб при рівні значущості $\alpha$ перевірити нульову гіпотезу про рівність нулю генерального коефіцієнта рангової кореляції Кендалла при конкуруючій гіпотезі $\mathrm{H}_{1}: \tau \neq 0$, обчислимо критичну точку:

де $\mathrm{n}$ - обсяг вибірки;

$$
T_{k p}=z_{k p} \cdot \sqrt{\frac{2(2 n+5)}{9 n(n-1)}}
$$

$Z_{\mathrm{kn}}$ - критична точка двосторонньої критичної області, яку знаходять по таблиці функції Лапласа за рівності $\Phi\left(\mathrm{z}_{\mathrm{kp}}\right)=(1-\alpha) / 2$.

Якщо $|\tau|<\mathrm{T}_{\mathrm{kv}}-$ немає підстав відкинути нульову гіпотезу про те, що ранговий кореляційний зв'язок між якісними ознаками незначущий.

Якщо $|\tau|>\mathrm{T}_{\mathrm{kn}}-$ нульову гіпотезу відкидають. А приймають гіпотезу про те, що між якісними ознаками існує значущий ранговий кореляційний зв’язок.

Знайдемо критичну точку zkp: $\Phi(\mathrm{z} \mathrm{kp})=(1-\alpha) / 2=(1-0,05) / 2=0,475$.

За даними таблиці Лапласа знаходимо $\mathrm{z}_{\mathrm{kp}}=1,96$. Знайдемо критичну точку:

$$
T_{k p}=1,96 \cdot \sqrt{\frac{2(2 \cdot 7+5)}{9 \cdot 7(7-1)}}=0,62 .
$$

Так як $\tau>$ Tkp, а саме $0,9>0,62$ - відкидаємо нульову гіпотезу про те, що ранговий кореляційний зв'язок між $\mathrm{X}$ (кількість керівників, які обрали діяльність в певній управлінській ситуації) та Y (обсяг чистого прибутку в тис. грн.) незначущий. А приймаємо гіпотезу $\mathrm{H}_{1}$ про те, що ранговий кореляційний зв'язок між $\mathrm{X}$ (кількість керівників, які обрали діяльність в певній управлінській ситуації) та Ү (обсяг чистого прибутку в тис. грн.) за оцінками двох тестів $€$ значущим.

Отже, гіпотези про те, що зі зростанням групової взаємодії зростатиме результативність діяльності структурного підрозділу організації і навпаки підтверджено. Встановлено значний кореляційний зв'язок між аналізованими якісними ознакам за розрахунками рангових кореляційних коефіцієнтів Спірмена та Кендалла.

В таблиці 6 наведемо порівняльні показники, що відображають кореляційний зв'язок між кількістю керівників структурного підрозділу організації, які обрали діяльність в певній управлінській ситуації та результатом - обсягом чистого прибутку.

Табличя 6

Оцінка показників діяльності керівників структурних підрозділів організації

\begin{tabular}{|l|c|c|c|c|c|c|c|}
\hline \multicolumn{1}{|c|}{ Показник } & \multicolumn{7}{|c|}{ Типи управлінських ситуацій } \\
\cline { 2 - 9 } & 1 & 2 & 3 & 4 & 5 & 6 & 7 \\
\hline Групи керівників, осіб & 6 & 2 & 5 & 8 & 4 & 2 & 1 \\
\hline $\begin{array}{l}\text { У\% від загального числа } \\
\text { опитуваних (28 осіб) }\end{array}$ & 21,4 & 7,1 & 17,9 & 28,6 & 14,3 & 7,1 & 3,6 \\
\hline
\end{tabular}




\begin{tabular}{|l|c|c|c|c|c|c|c|}
\hline $\begin{array}{l}\text { Обсяг чистого прибутку, тис. } \\
\text { грн (середнє значення за } \\
\text { місяць - } 7500 \text { тис. грн) }\end{array}$ & 1900 & 650 & 1380 & 2100 & 820 & 400 & 250 \\
\hline $\begin{array}{l}\text { У \% до середнього за місяць } \\
\text { (середнє значення за місяць - } \\
7500 \text { тис. грн) }\end{array}$ & 25,33 & 8,67 & 18,40 & 28,00 & 10,93 & 5,33 & 3,33 \\
\hline
\end{tabular}

\section{Примітка. Розраховано автором}

Це свідчить про те, що існує залежність від виявлених переважаючих груп керівників відділень структурного підрозділу організації, які обрали певний тип управлінської ситуації та результатами групової взаємодії, що оцінено за показником середньої суми чистого прибутку. Залежно від отриманих результатів доцільно сформувати пропозиції керівникам 3 тим, щоб переглянути відповідність управлінській ситуації, в якій обраний стиль управління виявився ефективним.

Висновки. В ситуаційних моделях вибір стилів управління відбувається залежно від рівня ідентифікованого типу НПС та від складності управлінської ситуації. Рівень складності управлінської ситуації залежить від ситуаційних змінних (чинників): відносин керівника 3 підлеглими (сприятливі, несприятливі), структури завдань (структуровані, неструктуровані), посадові повноваження (сильний, слабкий). Вказані ситуаційні змінні визначають рівень ситуаційного контролю, що визначається як «ступінь, в якій ситуація керівництва дозволяє лідеру контролювати та впливати на поведінку своєї групи».

Виявлено, що керівник, орієнтований на стосунки, $є$ найбільш ефективним, коли ситуаційні фактори поєднуються і є сприятливими для керівника, який має помірний контроль над ситуацією. Якщо три ситуаційних чинника створюють ситуацію, що є дуже сприятливою або дуже несприятливою для керівника, очікується, що керівники, орієнтовані на завдання, будуть ефективнішими. Керівник, який прийняв певний стиль управління, повинен відповідати управлінській ситуації, в якій цей стиль був би більш ефективним. Використання кожного із запропонованих стилів управління залежить від характеристик складності управлінської ситуації.

Доведено, що вибір стилю управління залежатиме від цілей досягнення діяльності, або цілей розвитку відносин між підлеглими. Керівники, які зосереджені на роботі, орієнтовані на завдання, піклуються, насамперед, про виконання завдання, про систему винагороди за виконану роботу. А керівники, зосереджені на відносини, прагнуть підвищити продуктивність праці через участь підлеглих у прийнятті рішень.

Сформуємо матрицю оцінки результатів тестування керівників структурних підрозділів комерційної організації, які наведемо в таблиці 7.

Таблиия 7

Матриця оцінки результатів тестування керівників структурних підрозділів організації

\begin{tabular}{|c|c|c|c|c|c|c|c|c|}
\hline \multirow{2}{*}{$\begin{array}{l}\text { Ситуаційні } \\
\text { змінні }\end{array}$} & \multicolumn{8}{|c|}{ Типи управлінських ситуацій } \\
\hline & 1 & 2 & 3 & 4 & 5 & 6 & 7 & 8 \\
\hline $\begin{array}{l}\text { Групування } \\
\text { керівників за } \\
\text { значенням НПС, } \\
\text { осіб }\end{array}$ & 6 & 2 & 5 & 8 & 4 & 2 & 1 & 0 \\
\hline $\begin{array}{l}\text { Відносини } \\
\text { «керівник- } \\
\text { підлеглий» }\end{array}$ & \multicolumn{4}{|c|}{ сприятливі } & \multicolumn{4}{|c|}{ несприятливі } \\
\hline $\begin{array}{l}\text { Структурованість } \\
\text { завдань }\end{array}$ & \multicolumn{2}{|c|}{ структуровані } & \multicolumn{2}{|c|}{ неструктуровані } & \multicolumn{2}{|c|}{ структуровані } & \multicolumn{2}{|c|}{ неструктуровані } \\
\hline $\begin{array}{l}\text { Посадові } \\
\text { повноваження }\end{array}$ & достатні & недостатні & достатні & недостатні & достатні & недостатні & достатні & недостатні \\
\hline Показник & 25,33 & 8,67 & 18,40 & 28,00 & 10,93 & 5,33 & 3,33 & 0 \\
\hline
\end{tabular}




\begin{tabular}{|l|l|l|l|l|l|l|}
\hline $\begin{array}{l}\text { ситуаційного } \\
\text { контролю, \% }\end{array}$ & & & & & & \\
\hline Стиль управління & \multicolumn{2}{|c|}{ орієнтований на завдання } & \multicolumn{2}{|c|}{ орієнтований на відносини } & на завдання \\
\hline
\end{tabular}

Примітка. Складено автором за [1, с. 149-190; 2, с. 137-149; 8, с. 344-348]

Виявлено, керівники мають дві основні мотивації: орієнтації на завдання та відносини. Опишемо їх з можливими компетенціями, які рекомендовані до удосконалення керівниками з використанням кожного стилю управління.

Керівники, орієнтовані на завдання (мають низькі бали НПС, а це 1-3 ситуації): 6 осіб, що обрали ситуацію 1 із показником ситуаційного контролю 25,33\%; 2 особи, що обрали ситуацію 2 із показником ситуаційного контролю 8,67\%; 5 осіб, що обрали ситуацію 3 із показником ситуаційного контролю 18,4\%), зосереджуються на деталях, є автократичними у прийнятті рішень, вимагають та контролюють виконання завдань проте немотивовані на розвиток відносин, які $є$ хорошими; керівник легко досягає встановлених показників, а завдання, що виконуються, $є$ чіткими та зрозумілими (ситуації 1,2 ).

Керівник $є$ вимогливим контролером, який стежить, щоб плани виконувалися, регламенти дотримувалися. А якщо щось відбувається неправильно, може розглядатися як результат недопрацювань, а винний повинен бути виявлений і покараний (ситуація 1,3 ). Керівники ставлять цілі і завдання, приймають рішення, підлеглі зобов'язані їх виконувати.

Реалізація стилю управління, орієнтованому на завдання в ситуаціях 1-3 дозволяє досягти високої продуктивності праці в короткостроковому періоді. Однак слід враховувати і ризики блокування креативності і самостійності співробітників, що може погіршити відносини в колективі. Турбота про зміцнення посадових повноважень керівника (ситуація 1,3 ) може негативно відобразитись на результатах діяльності.

У ситуаціях 1-3 найбільш відповідним буде стиль управління, орієнтований на завдання, тому що відносини між керівником і підлеглими вже хороші. Керівнику не потрібно витрачати багато часу на підтримку цих відносин. Оскільки керівник може мати як достатні так і недостатні посадові повноваження, проте завдання структурованими, тому підлеглі за вказівкам керівника їх виконують.

У ситуації 4 (8 особи із показником ситуаційного контролю 28\%) керівники відчувають загрозу через неоднозначність виконанні нечітких завдань, відсутність підтримки групи, недостатні посадові повноваження. Керівник, орієнтований на завдання може перешкодити творчий пошук групи у вирішенні неструктурованих завдань. Керівнику властивий колегіальний стиль управління, при якому кожен співробітник має свою точку зору. Підлеглі докладають максимум зусиль для досягнення найкращого результату на шляху до досягнення мети і не потребують суворого контролю.

Отже, потенційні переваги орієнтованого на завдання стилю управління - це швидкість дії та прийняття рішень, єдність мети і суворий контроль за роботою підлеглих.

У ситуації 5 (4 особи із показником ситуаційного контролю 10,93\%) керівник прагне знайти найкращі і найбільш ефективні рішення, щоб усі учасники вносили значний внесок і відчували б почуття задоволення від досягнутого. Якщо керівник має високе значення НПС звертається залучення до участі в прийнятті рішень, міжособистісного управління, які використовувати доцільно у випадках виникаючих конфліктів або нечіткого завдання.

Керівники, орієнтовані на відносини (мають вищі бали НПС, а це ситуації 6 (2 особи із показником ситуаційного контролю 5,33\%), 7 (1 особа із показником ситуаційного контролю $3,33 \%)$ ) не зосереджені на деталях виконання завдання, з низькими цілями на роботу, проте вагомим для керівника стає формування сприятливих відносин в колективі. Продуктивність праці є важливою, але налагодження стосунків - важливіше. Рекомендовані інструменти: співробітників не примушують працювати, а заохочують виконання їх бажань, задоволення інтересів. Помилки співробітників сприймаються для удосконалення в майбутньому, так як 
вони хороші професіонали і виконують справу настільки добре, наскільки можуть. Нові цілі або ідеї, здатні викликати труднощі не лякають керівника.

Подальше зростання значення НПС до 8 балів (ситуація 8 (не виявлена в ході дослідження)) свідчить про те, що відносини $\epsilon$ поганими в колективі, підлеглі $\epsilon$ незгуртованими, завдання незрозумілими, а посадові повноваження недостатніми. Натомість, керівник ініціює розвиток бюрократичної структури, прагне управління групою та здобути сильнішу позицію. Керівникам в такій ситуації потрібно виконання завдання будь-якою ціною, самодержавний стиль прийняття рішень. Підлеглі відмовляються бути згуртованими, завдання $є$ неструктурованими. однозначними, і реагують на відкликання, що призводить до неефективних результатів в управлінні. Ризики: усунення керівника; перешкоди виконання групових завдань, надмірне управління.

Отже, потенційні переваги орієнтованого на відносини стилю управління - це прояв турботи про благополуччя підлеглих, підлеглі мотивовані потребами більш високого рівня, стимулювання зацікавленості підлеглих у виконанні конкретних завдань.

В цілому, 3 восьми аналізованих управлінських ситуацій ситуація $1 \epsilon$ найбільш сприятливою для керівника. Це пояснюється тим, в цій ситуації відносини «керівникпідлеглий» хороші, завдання структуровані, посадові повноваження достатні. На противагу цьому ситуація 8 найменш сприятлива, тому що відносини «керівник-підлеглий» погані, завдання неструктуровані, посадові повноваження недостатні. I в цій ситуації 8 ефективнішим стилем управління буде орієнтація на завдання.

Результати засвідчили, що продуктивність керівників, орієнтованих на завдання середніх лідерів, як правило, перевершує показники високих значень НПС у аналізованих управлінських ситуаціях. Запропоновано інструменти удосконаленні реалізації виявлених стилів управління. 3 врахуванням ситуаційних змінних: взаємодії керівника та підлеглих, контрольованих показників та виконаних завдань.

Визначено та підібрано рекомендований стиль управління керівнику, здатного забезпечити гнучке керівництво в таблиці 8.

Таблиия 8

Рекомендовані стилі управління

\begin{tabular}{|c|c|c|c|}
\hline & \multicolumn{3}{|c|}{ Показник ситуаційного контролю } \\
\hline & Низький & Середній & Високий \\
\hline Керівник, & Директивний, орієнтований & Напружений, & Впевнений в собі, \\
орієнтований на & на завдання, серйозний, & цілеспрямований, & уважний, і підтримуючий, \\
завдання & мало турботи про інших & владний, надмірно & усуває перешкоди на \\
(Низький бал НПС) & Ситуація & контролюючий, уважний & шлях до мети \\
\hline Керівник, & Напружений і нервовий; & Поміркований, відкритий & Набридливий, віддалений, \\
орієнтований на & учай та пропозицій; & егоцентричний, \\
стосунки & учасник групового & кацікавлений у вирішення & автократичний, \\
(Високий бал НПС) & конфлікту; нерішучий & конфліктів & заважає груповій роботі \\
\hline
\end{tabular}

Примітка. Складено автором за [1, с. 149-190; 2, с. 137-149; 8, с. 344-348]

Якщо стиль управління керівника відповідає управлінській ситуації, то діяльність очолюваного ним структурного підрозділу буде ефективною. Оскільки стиль управління є постійним, то ефективність діяльності керівника змінюватиметься залежно від управлінської ситуації. Модель Ф.Е. Фідлера передбачає, що лідери з низьким рівнем НПС, мотивовані завданнями, будуть ефективними у високому та низькому ситуаційному контролі. Тоді як керівники, мотивовані стосунками, будуть ефективними в умовах помірного ситуаційного контролю.

Практичність використання підходу вибору стилю лідерства за методом Ф.Е. Фідлера в ситуаційному менеджменту полягає у тому, що керівники можуть оцінити стиль управління та ситуацію з метою прогнозування ефективності їх діяльності; керівники 
можуть зосередитись на зміні управлінської ситуації відповідно до їх стилю, а не навпаки; налагодження хороших відносин з підлеглими є апріорі метою управління і це може компенсуватись достатніми або недостатніми посадовими повноваженнями; керівники можуть деталізувати неструктуровані завдання, отримавши досвід управління в умовах невизначеності.

\title{
References
}

1.Fiedler, F.E. (1964) Contingency model of leadership effectiveness. Advances in experimental social psychology. New York, №1. P. 149-190.

2. Fidler, F.E. (1968) Personality and situational determinants of leadership effectiveness. Group dinamics. Research and theory. N. Y.: Harper \& Brothers, P. 137-149.

3. Fiedler, F., Garcia, J. (1987) New Approaches to leadership, cognitive resources and organizational performance. New York: John Wiley and Sons. $240 \mathrm{p}$.

4. Schermerhorn, J.R. Jr. (2011) Introduction to Management $11^{\text {th }}$ edition. New York: John Wiley and Sons.

5.Gold, J., Thorpe, R. \& Mumford, A. (2010) Handbook of leadership and management development. Gower Publishing.

6.Fiedler, F. E. (1967) A theory of leadership effectiveness. New York: McGraw-Hill.

7.Hunt, J. G. (1967) A test of the contingency model in three organizations: Urbana: University of Illinois Press.

8. Reviewed Work: A Theory of Leadership Effectiveness. by Fred E. Fiedler Review by: Ralph N. Campbell Campbell, R. (1968). Administrative Science Quarterly, 13(2), 344-348. doi:10.2307/2391461

Дата подання публікації 20.03.2021 p.

УДК 339.56

Галас Л.І., аспірант Halas L. Postgraduate student https://orcid.org/0000-0002-3677-0045 Дзямулич M.I., к.е.н., доцент Dziamulych M. Candidate of Economic Sciences, Associate Professor https://orcid.org/0000-0003-3714-5062

Шматковська T.O., к.е.н., доцент Shmatkovska T. Candidate of Economic Sciences, Associate Professor https://orcid.org/0000-0003-2771-9982

\section{ОСОБЛИВОСТІ ЕКСПОРТНОЇ ДІЯЛЬНОСТІ СІЛЬСЬКОГОСПОДАРСЬКИХ ПІДПРИЕМСТВ В УКРАЇНІ}

\author{
Прикарпатський наиіональний університет імені Василя Стефаника \\ Луиький національний технічний університет \\ Волинський національний університет імені Лесі Украӥнки
}

\begin{abstract}
Специфіка сучасного етапу розвитку агросектору в Україні значною мірою залежить від ефективності діяльності національних сільськогосподарських виробників на зовнішніх ринках. Зокрема, особливого значення в аспекті євроінтеграції та відкриття нових ринків для українських підприємств набуває підвищення їх експортної активності у сфері збуту продукції агропромислового комплексу. При цьому важливим компонентом забезпечення такої ефективності є об'єктивна потреба в досягненні належного рівня конкурентоспроможності національних підприємств на зовнішніх ринках, яка дозволить їм переорієнтуватися 3 операцій по збуту сільськогосподарської сировини на торгівлю продуктами переробного комплексу аграрного сектору. Розширення торгівлі продукцією переробного комплексу сприятиме не лише загальному зростанню прибутковості сільськогосподарських виробників від експортних операцій, але й дозволить їм здійснювати діяльністю по розширенню уже наявних ринків збуту завдяки збільшенню пропозиції за товарними групами.
\end{abstract}

В статті розглянуто сучасні особливості експортної діяльності сільськогосподарських підприємств України в умовах виходу на нові ринки в аспекті економічної глобалізації. Визначено, що забезпечення підвищення ефективності експортної діяльності підприємств агросектору повинне передбачати застосування системи всебічного аналізу та планування специфіки експортних операцій 3 
врахуванням конкретних ринкових умов та вимог. При цьому головною метою підприємств повинна залишатися орієнтацію на нарощення обсягів збуту як сільськогосподарської сировини, так і продукції переробної сфери на зовнішніх ринках. Головним аспектом такого підходу повинне бути забезпечення 